\title{
An Exploration on Stress Management with Reference to Signware Technology Pvt. Ltd Based at Chennai
}

\author{
S. Joshna, S Praveen Kumar, K. Poovarasan
}

\begin{abstract}
Stress is a psychological agony caused to the representatives in the work territory because of the job they carry out. Stress can be just characterized as outside power following up on an individual and which gradually hinders his effectiveness. This exploration study fundamentally manages Employee Stress at Signware Technologies. It additionally centers around current feeling of anxiety and main considerations affecting representatives worry at work spot.
\end{abstract}

\section{INTRODUCTION}

Stress is a psychological agony caused to the representatives in the work territory because of the job they carry out. Stress can be just characterized as outside power following up on an individual and which gradually hinders his effectiveness [1,2].

Stress delivers various indications which shift as per people, conditions, and sincerity. More data is given underneath on the most proficient method to gauge feelings of anxiety, find out about pressure the board models and practice strategies that will decrease pressure and advance a

The various type of stress that an employee faces in his
a) Psychological stress
b) Organisational stress
c) Societal stress

The association is adjusting a few practices to limit the worry of representatives by giving great preparing and earlier guidance in regards to the work they need to perform. Appropriate relationship should exist between the bosses and subordinates. Great workplace ought to be kept up [6-8]. positive way of life [3-5]. career are broadly classified into three types
S. Joshna , Department of Management Studies, Bharath Institute of Higher Education and Research, Chennai, Tamilnadu, India

S Praveen Kumar, Department of Management Studies, Bharath Institute of Higher Education and Research, Chennai, Tamilnadu, India

K. Poovarasan, Department of Management Studies, Bharath Institute of Higher Education and Research, Chennai, Tamilnadu, India
Revised Manuscript Received on July 22, 2019.

\section{OBJECTIVES}

- To discover the degree of worry among the representatives in Signware Technologies

- To distinguish the results of the worry among the workers

- To distinguish the components causing worry among the representatives

- To assess the effect of worry in the authoritative execution

- To carry the adapting methodologies to conquer the pressure

\section{NEED FOR THE STUDY}

The coming of innovative upset in varying backgrounds combined with the globalization and privatization approaches have radically changed customary examples in all segments. The assembling division has experienced quick and striking changes because of globalization and progression, expanded challenge because of the passage of increasingly private (corporate) parts, cutting back, presentation of new innovations, and so on. Because of these changes, the workers in the assembling part are encountering an abnormal state of pressure. Whenever influenced the social, conservative, and mental areas of the officials and their relations. The present examination proposes to deliver explicit issues identified with pressure the executives among the workers in SIGNWARE TECHNOLOGIES [9-14].

\section{SCOPE}

The investigation is led to consider the feeling of anxiety and its administration among the workers of Signware Technologies. This investigation is centered around the assembling area and the examination is confined to the business $[15,16]$

\section{RESEARCH METHODOLOGY}

Research approach: Survey research is the systematic gathering of data from respondents through questionnaire.

Percentage Analysis:Percentage analysis is used to find out the percentage of the respondents responses for the questions $[17,18]$.

Chi-Square Test: Analysis of

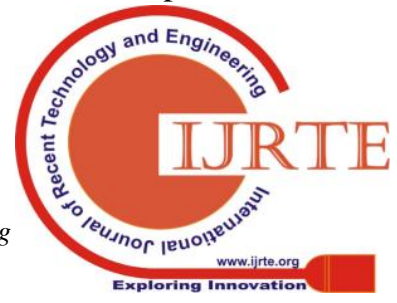


Chi-Square was used to determine the relationship and impact of one variable over another. The following analyzes are used you $[19,20]$.

\section{Techniques of STRess Management}

\section{A. Autogenic training}

Autogenic preparing is an unwinding strategy created by the German therapist Johannes Heinrich Schultz and first distributed in 1932.

The system includes the day by day routine with regards to sessions that last around 15 minutes, normally in the first part of the day, at noon, and at night. During every session, the professional will rehash a lot of representations that initiate a condition of unwinding. The strategy can be utilized to mitigate many pressure actuated psychosomatic issue [21-23].

Schultz underlined parallels to methods in yoga and reflection. It is a strategy for affecting one's autonomic sensory system. In 1963 Luthe found the centrality of "autogenic releases", paroxistic wonders of engine, sensorial, visual and passionate nature identified with the horrible history of the patient, and built up the technique for "Autogenic Abreaction". His supporter Luis de Rivera, a McGill prepared therapist, brought psychodynamic ideas into Luthe's methodology, creating "Autogenic Analysis" as another strategy for revealing the oblivious [24-26].

Example of an Autogenic Training Session

"my right arm is heavy"

"my arms and legs are heavy and warm"

"my heartbeat is calm and regular"

"my solar plexus is warm"

"my forehead is cool"

"my neck and shoulders are heavy"

"I am at peace

\section{B. Cognitive therapy}

Psychological therapy aims at enabling the patient to conquer complications by acknowledging and altering unnecessary thinking and enthusiastic responses. This includes assisting nurses develop the ability to adjust beliefs, differentiate contorted deduction, identify with others in different respects, and evolve methods. Treatment depends on joint effort among patient and advisor and on testing convictions [27,28].

A straightforward model may outline the rule of how CT functions: having committed an error at work, an individual may accept, "I'm futile and can't do anything directly at work." Strongly accepting this at that point will in general compound their mind-set. The issue might be exacerbated further on the off chance that the individual responds by staying away from exercises and, at that point behaviourally affirming the negative conviction to themselves [29].

Subsequently, any versatile reaction and further useful outcomes become improbable, which fortifies the first conviction of being "futile". In treatment, the last model could be recognized as an unavoidable outcome or "issue cycle", and the endeavors of the specialist and customer would be aimed at cooperating to transform it. This is finished by tending to the manner in which the customer thinks and acts in light of comparative circumstances and by growing progressively adaptable approaches to think and react, including diminishing the shirking of exercises. In the event that, therefore, the patient escapes the negative idea designs and broken practices, the negative emotions might be soothed after some time.

\section{Exercise}

Physical exercise is any significant activity that enhances or maintains physical well-being and health in general. It's done for various purposes. It additionally improves psychological well-being, counteracts gloom, advances or keep up positive confidence, and can even expand a person's sex advance or self-perception, which again is likewise connected with more elevated amounts of confidence. Youth weight is a developing worldwide concern and physical exercise may help decline the impacts of youth corpulence in created nations [30].

\section{Meditation}

Contemplation alludes to any of a group of practices where the specialist prepares his or her psyche or self-prompts a method of awareness so as to understand some advantage.

Contemplation is commonly an inner, individual practice and managed with no outside association, aside from maybe petition dots to tally supplications, however numerous professionals of reflection may depend on outer items, for example, light blazes as focuses on which to concentrate as a guide to the procedure. Reflection regularly includes summoning or developing an inclination or inward state, for example, empathy, or taking care of a particular point of convergence. The term can allude to the state itself, just as to practices or systems utilized to develop the state.

A recent report by the U.S. government found that almost $9.4 \%$ of U.S. grown-ups (more than 20 million) included rehearsed contemplation inside the previous a year, up from $7.6 \%$ (in excess of 15 million individuals) in 2002.

Since the 1960s, reflection has been the focal point of expanding logical research of uneven thoroughness and quality. In more than 1,000 distributed research thinks about, different strategies for contemplation have been connected to changes in digestion, circulatory strain, cerebrum initiation, and other real procedures. Reflection has been utilized in clinical settings as a technique for stress and agony decrease [31-33].

Chart No:1 Respondent's Level of Agreement on Meeting Job Demand 


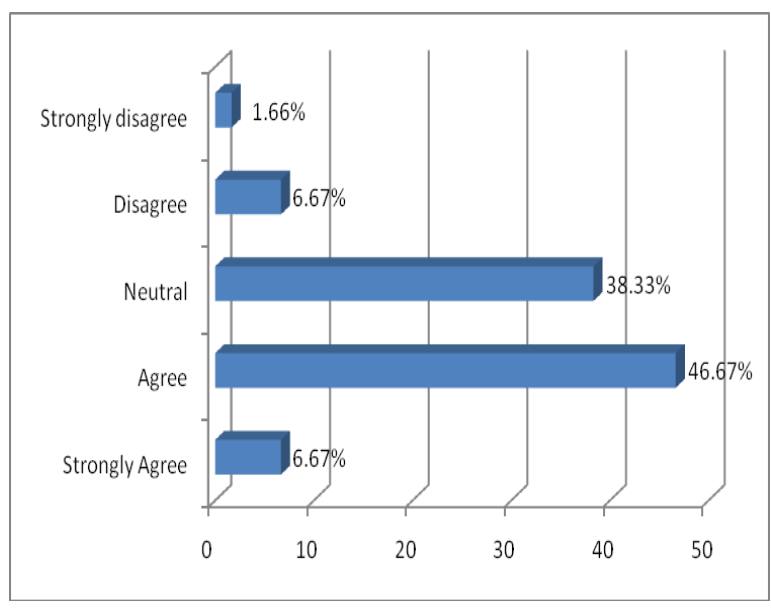

Chart No: 2 Respondents Level of Agreement on Inadequate Training

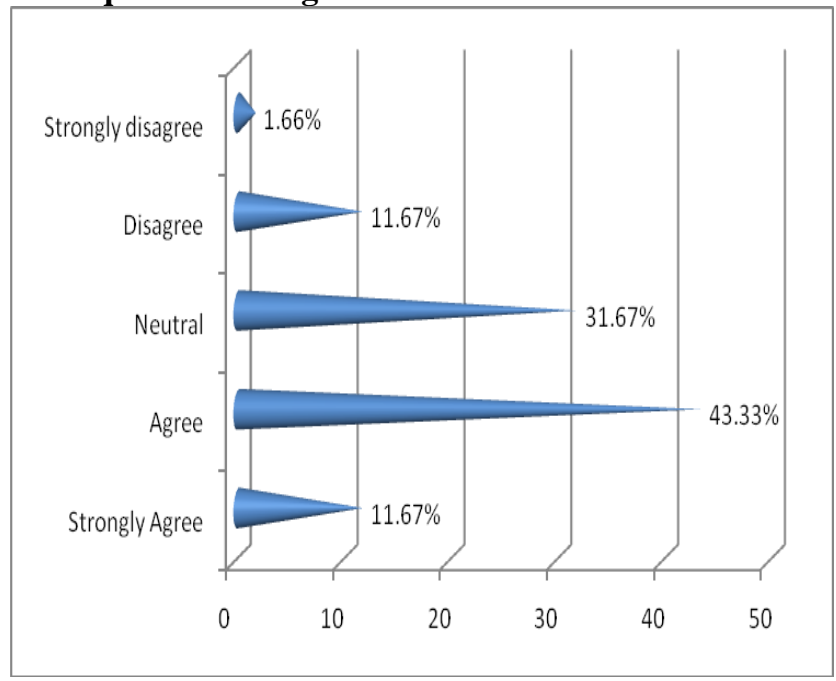

\section{Inference:}

The chart shows $43.33 \%$ of the respondents agree that the training given to them is inadequate and $38.33 \%$ of them are neutral on the training given to them.

Chart No: 2.1.10 Respondent's Level of Agreement on Getting Necessary Information to Perform Their Job

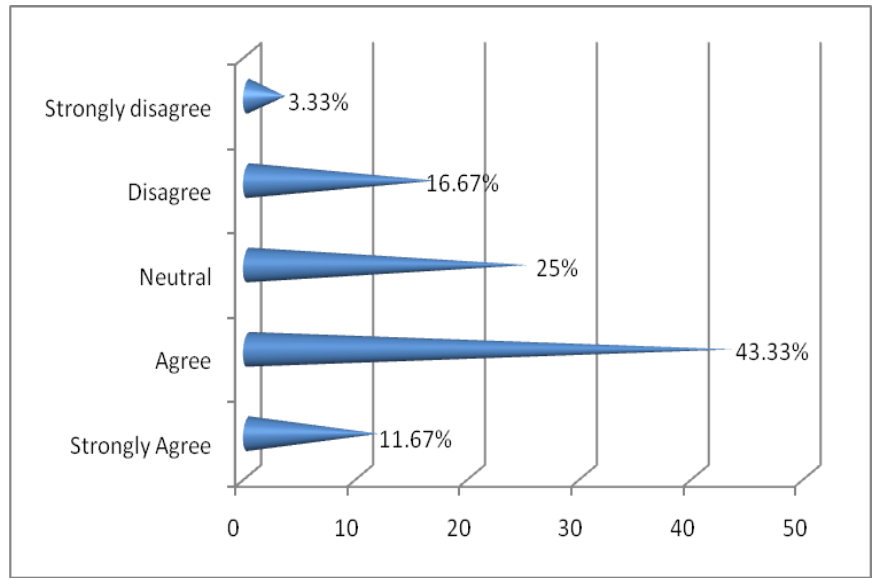

Chart No: 2.1.11 Respondents Level of Agreement on Usage of Training Knowledge and Expertise in Their Work

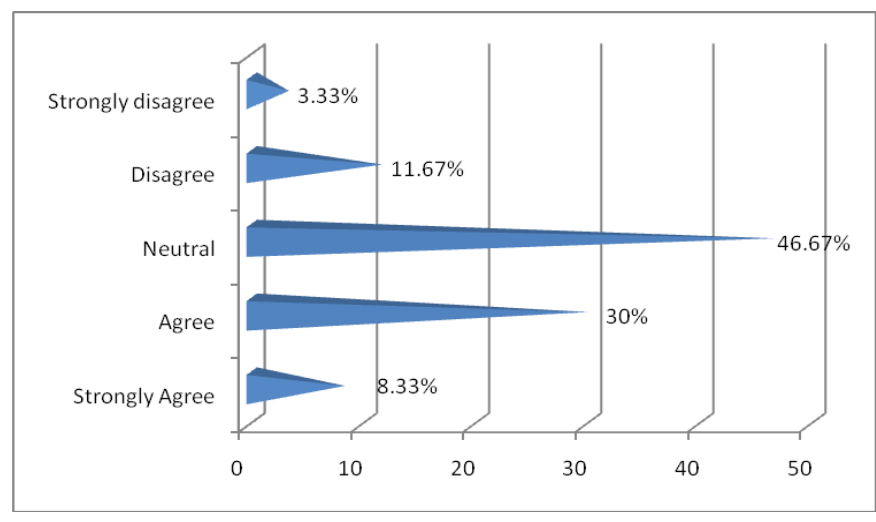

\section{Inference:}

The chart shows $46.67 \%$ of the respondents have neutral opinion on using their training in work and $30 \%$ of them agree in using their training and expertise in work. $3.33 \%$ say they don't use their knowledge from training and expertise by disagree the statement

Chart No: 2.1.12 Respondents Level of Agreement on Competition with Colleagues

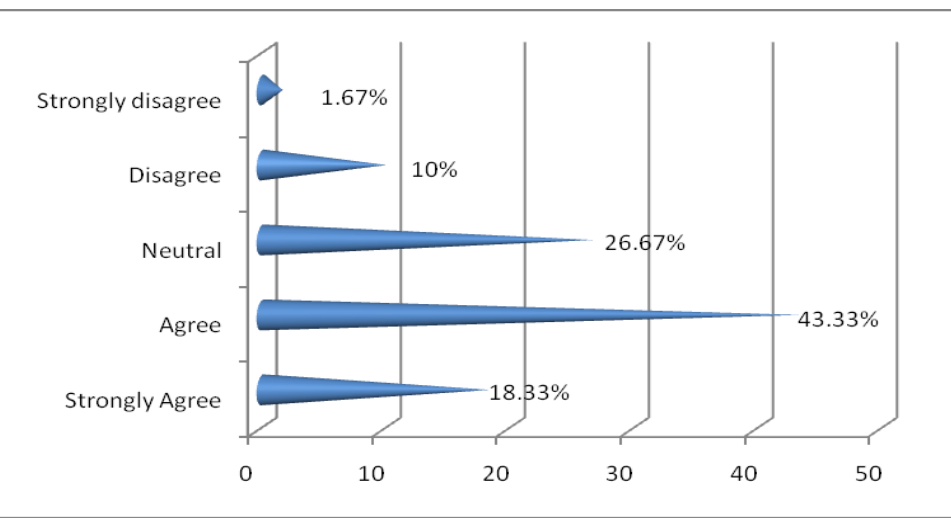

\section{Inference:}

The chart shows $43.33 \%$ of the respondents agree in their competition with colleagues and $26.67 \%$ of them are neutral in competing with colleagues.

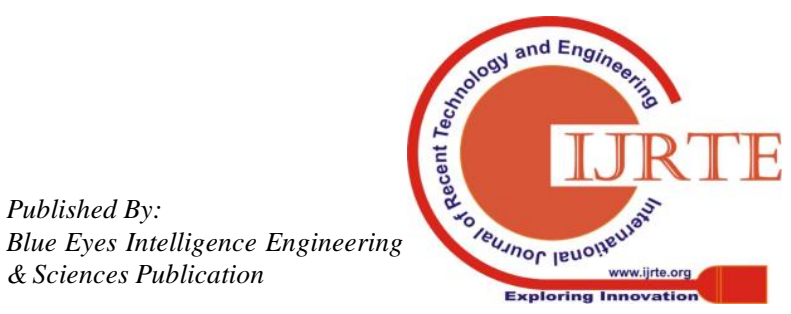


Chart No: 2.1.13 Respondents Level of Agreement on Cordial Relationship with Peers and Colleagues

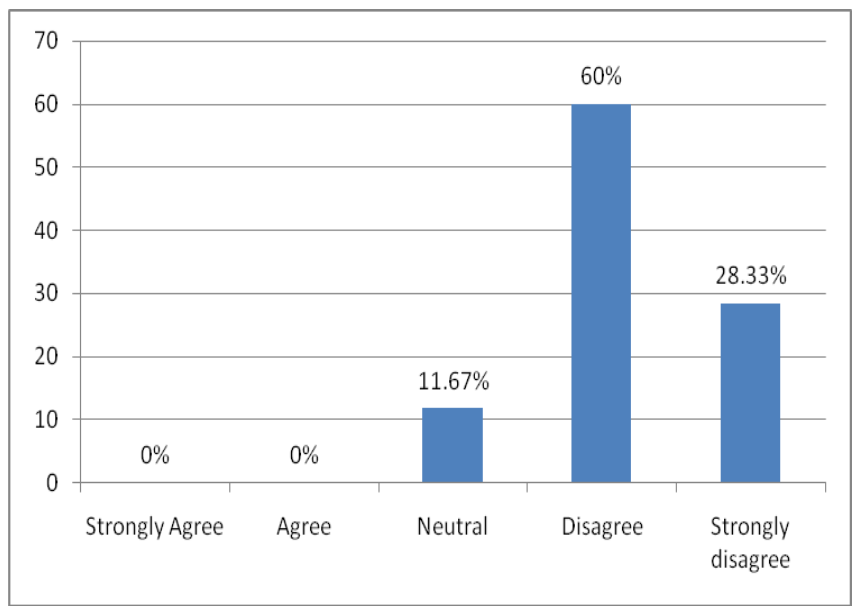

\section{Inference:}

The chart shows $60 \% \%$ of the respondents disagree because they do not have cordial relationship and $28.33 \%$ of them strongly disagree in this statement.

\section{STATISTICAL ANALYSIS-CHI SQUARE TEST}

\section{A. Age of the assenters Vs Level of Agreement on the} Mood Swings Due To Work Pressure

NULL HYPOTHESIS (H0): There is no connection between the assenters ' era and the amount of consensus on the mood swing

ALTERNATIVE HYPOTHESIS (H1) job stress: there is a link between the assenters ' era and the job stress owing to their mood swing.

\section{Table No. 2.2.1}

\begin{tabular}{|l|l|l|l|l|l|l|}
\hline & \multicolumn{6}{|c|}{ Level of Agreement On The Mood Swings Caused Due To Work Pressure } \\
\hline AGE & $\begin{array}{l}\text { Strongly } \\
\text { Agree }\end{array}$ & Agree & Neutral & $\begin{array}{l}\text { Disagr } \\
\text { ee }\end{array}$ & $\begin{array}{l}\text { Strongly } \\
\text { Disagree }\end{array}$ & TOTAL \\
\hline $\begin{array}{l}<\mathbf{3 0} \\
\text { years }\end{array}$ & $4(0.8)$ & $0(0.6)$ & $0(0.8)$ & $0(1.2)$ & $0(0.4)$ & $\mathbf{4}$ \\
\hline $\mathbf{3 1 - 4 0}$ & $16(15.6)$ & $12(12.0)$ & $20(14.4)$ & $\begin{array}{l}18(21 . \\
6)\end{array}$ & $6(8.4)$ & $\mathbf{7 2}$ \\
\hline $\mathbf{4 1 - 5 0}$ & $6(8.6)$ & $8(6.6)$ & $4(8.0)$ & $\begin{array}{l}14(12 . \\
0)\end{array}$ & $8(4.6)$ & $\mathbf{4 0}$ \\
\hline$>\mathbf{5 0}$ & $0(0.8)$ & $0(0.6)$ & $0(0.8)$ & $4(1.2)$ & $0(0.4)$ & $\mathbf{4}$ \\
\hline Total & $\mathbf{2 6}$ & $\mathbf{2 0}$ & $\mathbf{2 4}$ & $\mathbf{3 6}$ & $\mathbf{1 4}$ & $\mathbf{1 2 0}$ \\
\hline
\end{tabular}

Where Chi-Square value $=16.535$

$P$ value $=0.005$
B. Age of the assenters Vs Level of Agreement on Ability to Meet Physical Requirements of the Job

Table No.2.2.3

\begin{tabular}{|l|l|l|l|l|l|l|}
\hline \multicolumn{5}{|c|}{ Level of Agreement On Ability To Meet Physical Requirements Of The Job } \\
\hline AGE & $\begin{array}{l}\text { Strongly } \\
\text { Agree }\end{array}$ & Agree & Neutral & Disagree & $\begin{array}{l}\text { Strongly } \\
\text { Disagree }\end{array}$ & TOTAL \\
\hline$<30$ years & $0(0.4)$ & $4(1.6)$ & $0(1.4)$ & $0(0.6)$ & $0(0.0)$ & $\mathbf{4}$ \\
\hline $\mathbf{3 1 - 4 0}$ & $2(6.0)$ & $24(28.8)$ & $26(25.2)$ & $18(10.8)$ & $2(1.2)$ & $\mathbf{7 2}$ \\
\hline $\mathbf{4 1 - 5 0}$ & $8(3.4)$ & $16(16.0)$ & $16(14.0)$ & $0(6.0)$ & $0(0.6)$ & $\mathbf{4 0}$ \\
\hline$>\mathbf{5 0}$ & $0(0.4)$ & $4(1.6)$ & $0(1.4)$ & $0(0.6)$ & $0(0.0)$ & $\mathbf{4}$ \\
\hline Total & $\mathbf{1 0}$ & $\mathbf{4 8}$ & $\mathbf{4 2}$ & $\mathbf{1 8}$ & $\mathbf{2}$ & $\mathbf{1 2 0}$ \\
\hline
\end{tabular}

Where Chi-Square value $=17.156$

$\mathrm{P}$ value $=0.024$

\section{Age of the assenters Vs Level of Agreement on Considerable Stress in Work}

NULL HYPOTHESIS (H0): There is no connection on significant pressure between the participants ' era and the respondents ' amount of consensus.

ALTERNATIVE HYPOTHESIS (H1): The age of the participants is associated with the point of consensus of the participants on significant stress.

Table No.2.2.3

\begin{tabular}{|l|l|l|l|l|l|l|}
\hline \multicolumn{7}{|c|}{ Level of Agreement On Considerable Stress in Work } \\
\hline AGE & $\begin{array}{l}\text { Strongly } \\
\text { Agree }\end{array}$ & Agree & Neutral & Disagree & $\begin{array}{l}\text { Strongly } \\
\text { Disagree }\end{array}$ & TOTAL \\
\hline$<30$ years & $0(0.2)$ & $2(0.8)$ & $2(1.2)$ & $0(1.2)$ & $0(0.6)$ & $\mathbf{4}$ \\
\hline $\mathbf{3 1 - 4 0}$ & $0(3.6)$ & $16(15.6)$ & $26(20.4)$ & $26(22.8)$ & $4(9.6)$ & $\mathbf{7 2}$ \\
\hline $\mathbf{4 1 - 5 0}$ & $6(2.0)$ & $8(8.6)$ & $6(11.4)$ & $8(12.6)$ & $12(5.4)$ & $\mathbf{4 0}$ \\
\hline$>\mathbf{5 0}$ & $0(0.2)$ & $0(0.8)$ & $0(1.2)$ & $2(1.2)$ & $0(0.6)$ & $\mathbf{4}$ \\
\hline Total & $\mathbf{6}$ & $\mathbf{2 6}$ & $\mathbf{3 4}$ & $\mathbf{3 8}$ & $\mathbf{1 6}$ & $\mathbf{1 2 0}$ \\
\hline
\end{tabular}

Where Chi-Square value $=21.127$

$\mathrm{P}$ value $=0.049$

\section{Interpretation:}

Since the P-value is less than 0.05 So there is association between the age of the respondents and agreement level of the respondents on considerable stress.

\section{RESULTS AND DISCUSSION}

1. The study reveals that $62 \%$ of the employees are male.

2. $60 \%$ of assenter are in the age group of $31-40,33 \%$ of the assenter are in the age group of

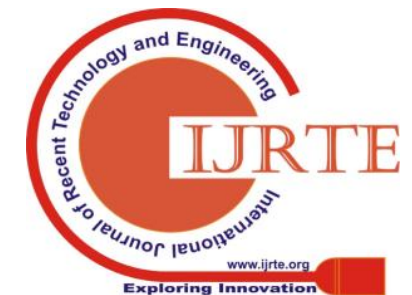


41-50.

$3.43 \%$ of respondent are Under Graduate, $25 \%$ of the respondent are Post Graduate, 20\% of respondent are Diploma.

4. $41 \%$ have been working for more than 10 years, $36 \%$ of the assenter have been working for more than 20 years.

$5.38 \%$ of the respondents agree that they have heavy work load and $16 \%$ of the respondents did not agree that they are having heavy work load.

$6.46 \%$ of the respondents agree that they cannot meet out the demand of their job.

$7.33 \%$ of the assenter agree and $26 \%$ of the assenter disagree that their work is monotonous.

$8.43 \%$ of the assenter agree and $11 \%$ of the assenter disagree that the training given for them is inadequate.

$9.43 \%$ of the assenter agree, $25 \%$ of the assenter are neutral and $16 \%$ of the respondents disagree that no necessary information is provided to perform their job.

10. $30 \%$ of the assenter agree and $46 \%$ of the assenter are neutral that they are not able to use their training and expertise in their work.

11. $43 \%$ of the assenter agree, $26 \%$ of the assenter are neutral and $10 \%$ of respondents disagree in competing with colleagues at work.

12. $50 \%$ of the assenters are not satisfied in satisfying their superiors and juniors.

13. $38 \%$ of the assenter agree and $10 \%$ of the assenter disagree that the work is not related to their interest.

14. $75 \%$ of the assenter agree that they feel insecure in the working environment.

15. $50 \%$ of the assenter agree that they are not sure of what is expected of them.

16. $45 \%$ of the assenter agree and $13 \%$ of the respondents disagree that they feel tired at the end of the day.

17. $36 \%$ of the assenter agree and $35 \%$ of the assenter strongly agree that they have a good sleep without worrying about the work.

18. $40 \%$ of the assenter agree and $15 \%$ of the assenter disagree that they are not able to meet up their physical requirements.

19. $53 \%$ of the assenter agree and $16 \%$ of the assenter disagree that there is no time for relaxation on the job.

20. $58 \%$ of the assenter agree and $13 \%$ of the assenter disagree that they are emotionally drained from work.

21. $55 \%$ of the assenter agree

\section{CONCLUSION}

The investigator produced an effort to contemplate the comment on the officials worried in SIGNWARE TECHNOLOGIES, Chennai, during the examination. The various problems associated with the inquiry portion were created and properly handled and sensible provisions were created to overcome the stress of the employees. The accompanying elements have a cozy association with the worker stress age, training, sex, remaining task at hand, human connection, association with friends and partners and physical necessities.

It has been found out that factors like experience, shift, salary has no relationship with employee stress.

The conclusion of the study may assist the association to distinguish the stress factors from stress relief factors and to take effective steps to reduce the employee stress which will level to better performance.

\section{REFERENCES}

1. G BharthVajan R., Ramachandran S.,Psychographic dimensions of training,2016,International Journal of Pharmacy and Technology,V-8,I-4,P-23727-23729

2. Balakrishnan P., Bharthvajan R.,A study on human resource planning in hospitals in Chennai City,2014,International Journal of Applied Engineering Research,V-9,I-22,P-7503-7507

3. Priyadarsini P., Bharthvajan R.,Role of emotional intelligence training programme in reducing the stress of the nurses,2014,International Journal of Applied Engineering Research,V-9,I-22,P-7411-7421

4. Kerinab Beenu G., Bharthvajan R.,Empirical analysis on the cosmetic buying behavior of young women in South India,2014,International Journal of Applied Engineering Research,V-9,I-22,P-7361-7366

5. Balakrishnan P., Bharthvajan R.,Whistling in the wind,2014,International Journal of Applied Engineering Research,V-9,I-22,P-7586-7593

6. Krishnan B., Peter M.,Health hazards of Indian Bpo employee-an alarming issue,2014,International Journal of Applied Engineering Research,V-9,I-22,P-7336-7341

7. Kerinab Beenu G.H., Peter M.,Role of insurance in economic development,2014,International Journal of Applied Engineering Research,V-9,I-22,P-7532-7539

8. Balakrishnan P., Peter M., Priyadarsini P.,Efficiency of safety measures for wellbeing of employees in manufacturing industry,2014,International Journal of Applied Engineering Research,V-9,I-22,P-7376-7382

9. Anbarasi M., Praveen Kumar S.,Online sales promotions of herbal products and its effectiveness towards tanisha.com,2019,Indian Journal of Public Health Research and Development,V-10,I-1,P-195-200

10. Anbarasi M., Praveen Kumar S.,Various online marketing and promotions strategies to improve the validation towards the organic products in the pharmaceutical sectors, 2019,Indian Journal of Public Health Research and Development,V-10,I-1,P-263-269

11. Loganathan R., Praveen Kumar S.,Grievance handling a key factor for solving issues of employees in an organization,2014,International Journal of Applied Engineering Research,V-9,I-22,P-7483-7491

12. Loganathan R., Praveen Kumar S.,Study on preference of private label brands in super and Hypermarkets,2014,International Journal of Applied Engineering Research,V-9,I-22,P-7327-7335

13. Smitha M., Praveen Kumar S.,Understanding stress and its managementamong the nurses in Chennai city,2014,International Journal of Applied Engineering Research,V-9,I-22,P-7560-7565

14. Kerinab Beenu G.H., Praveen Kumar S.,A study on the investment behavior of Chennai investors in mutual fund schemes,2014,International Journal of Applied Engineering Research,V-9,I-22,P-7520-7525

15. Loganathan R., Praveen Kumar S.,Retention strategies key for organizational productivity,2014,International Journal of Applied Engineering Research,V-9,I-22,P-7443-7447

16. Pavithra J., Ganesan M., Brindha G.,State wise analysis of microfinance sector in India,2016, International Journal of Pharmacy and Technology,V-8,I-4,P-23417-23432

17. Pavithra J., Ganesan M.,A comparative study on microfinance in India and abroad,2016,International Journal of Applied Business and Economic Research,V-14,I-8,P-5471-5476

18. Pavithra J., Ganesan M.,A study on awareness and impact of micro-financial schemes,2016,International Journal of Applied Business and Economic Research,V-14,I-8,P-5449-5460

19. Senthilmurugan P., Pavithra J.,Consumer preference towards organised retailing with reference to Big Bazaar,2014,International Journal of Applied Engineering Research,V-9,I-22,P-7469-7475

20. Senthilmurugan P., Pavithra J.,Implication of social media marketing in growing healthcare industry,2014,International Journal of Applied Engineering Research,V-9,I-22,P-7448-7456

21. Loganathan R., Pavithra J.,Consumer perception towards private label brand over other brands in super markets and hypermarkets,2014,International Journal of Applied Engineering Research,V-9,I-22,P-7355-7360

22. Kerinab Beenu G., Pavithra J.,Tradeâ€"off between liquidity and profitability in logistics 


\section{An Exploration on Stress Management with Reference to Signware Technology Pvt. Ltd based at Chennai}

industry,2014,International Journal of Applied Engineering Research,V-9,I-22,P-7398-7401

23. Kerinab Beenu G., Pavithra J.,A study on the prospective consumerâ€ $€^{\mathbf{T M}_{\mathrm{S}}}$ perception towards utility cars in Chennai city,2014,International Journal of Applied Engineering Research,V-9,I-22,P-7526-7531

24. Pavithra J., Dilli Babu P., Ambuli T.V.,A study on budgetary control at Maruti Service Masters, Chennai,2014,International Journal of Applied Business and Economic Research,V-12,I-2,P-151-161

25. Pavithra J., Dilli Babu P., Ambuli T.V.,A study on customer satisfaction of retro Garments Pvt Ltd, Chennai,2014,International Journal of Applied Business and Economic Research,V-12,I-2,P-381-391

26. Kerinab Beenu G.H., Pavithra J., Senthilmurugan P.,A study on the influence of promotional activities for TATA ARIA among consumers in Chennai,2014,International Journal of Applied Engineering Research,V-9,I-22,P-7572-7578

27. Vijayaragavan S.P.,An investigative expert that's general FBG sensors,International Journal of Mechanical Engineering and Technology,V-8,I-8,PP-1500-1505,Y-2017

28. Vijayaragavan S.P.,Equalization routing protocol for Wi-Fi sensor strategy,International Journal of Mechanical Engineering and Technology,V-8,I-8,PP-1662-1666,Y-2017

29. Karthik B., Kiran Kumar T.V.U., Vijayaragavan P., Bharath Kumaran E.,Design of a digital PLL using $0.35 \hat{1}^{1} / 4 \mathrm{~m}$ CMOS technology,Middle East Journal of Scientific Research,V-18,I-12,PP-1803-1806,Y-2013

30. Kanniga E., Selvaramarathnam K., Sundararajan M.,Kandigital bike operating system,Middle - East Journal of Scientific Research,V

31. Jasmin M., Vigneshwaran T., Beulah Hemalatha S.,Design of power aware on chip embedded memory based FSM encoding in FPGA,International Journal of Applied Engineering Research,V-10,I-2,PP-4487-4496,Y-2015

32. Jasmin M.,Optimization techniques for low power VLSI circuits,Middle East Journal of Scientific Research,V-20,I-9,PP-1082-1087,Y-2014

33. Jasmin M., Vigneswaran T.,Fuzzy controller for error control of on - Chip communication,2017 International Conference on Algorithms, Methodology, Models and Applications in Emerging Technologies, ICAMMAET 2017,V-2017-January,I-,PP-1-5,Y-2017

\section{AUTHORS PROFILE}

S. Joshna, Student, Department of Managemen Studies, Bharath Institute of Higher Education and Research, Chennai, India

S Praveen Kumar Associate Professor, Department of Management Studies, Bharath Institute of Higher Education and Research, Chennai, India

K. Poovarasan, Student, Department of Management Studies, Bharath Institute of Higher Education and Research, Chennai, India 